УДК 618.11-008.64-02-092-06:618.177-08:618.17-089.888.11

DOI 10.11603/24116-4944.2019.2.10927

С.Г. В. Стрелко, О. А. Ночвіна

Медичний центр «Родинне джерело», Київ

Медичний центр «нномед - материнство тадитинство», Вінниця

\title{
РЕТРОСПЕКТИВНИЙ АНАЛІЗ ЕФЕКТИВНОСТІ ПРОГРАМ ДОПОМГЖНИХ РЕПРОДУКТИВНИХ ТЕХНОЛОГІЙ У ЖІНОК ІЗ РІЗНИМИ ФОРМАМИ БЕЗПЛІДДЯ
}

\begin{abstract}
Мета дослідження - аналіз ефективності застосування різних програм допоміжних репродуктивних технологій (ДРТ) у жінок із різними фрормами безпліддя за даними ретроспективного аналізу медичної документації.

Матеріали та методи. Проведено дослідження есрективності програм ДРТ шляхом ретроспективного аналізу причини та структури безпліддя, застосування різних методів ДРТ, настання вагітності та пологів у жінок із різними фоормами безпліддя, зокрема «поганих відповідачів» протягом 2013-2016 років.

Результати дослідження та їх обговорення. Доведено, що кількість жінок із різними формами безпліддя та, відповідно, циклів ДРТ невпинно зростає. Відзначено зростання частоти як жіночого, так і чоловічого безпліддя з приблизно однаковим відсотковим співвідношенням, з перевагою жіночого в 3,3 раза, та зміни структури суто жіночого безпліддя, де на перший план у 2016 році виходить трубно-перитонеальний фактор - 123/49,4 \% та ендометріоз - 89/35,7 \%. Також спостерігається невпинне зростання жінок із безпліддям старшої вікової категорії: жінки віком 35-39 років у 2013 році становили 27,4 \%, тоді як у 2016 році вже 31,7 \%. У віці понад 40 років у 2013 році звернулися 17,6 \% жінок, у 2016 році - 29,3 \%. При цьому, незважаючи на розвиток програм допоміжних репродуктивних технологій, особливо у жінок старшої вікової групи, та збільшення використання з 2013 по 2016 рік таких методик, як ICSI (57/45,8 та 248/81,1% відповідно), донація ооцитів (6/4,8 та 58/18,9 \% відповідно), цикли із переносом заморожених ембріонів (19/15,3 та 95/31,0 \% відповідно) та проведення передімплантаційної генетичної діагностики (Пгд) ембріонів (2/1,6 та 28/9,2% відповідно), особливо у жінок старшої вікової групи, кількість діагностованих клінічних вагітностей суттєво не відрізняється протягом 2013-2016 років.

Висновок. Представлені результати дослідження доводять, що вірогідність настання вагітності має зворотний зв'язок із віком жінки та її оваріальним резервом, що може бути предиктором низької оваріальної відповіді на контрольовану стимуляцію яєчників у програмах ДРТ.

Ключові слова: безпліддя; програми ДРТ; «погані відповідачі»; вік.

РЕТРОСПЕКТИВНЫЙ АНАЛИЗ ЭФФЕКТИВНОСТИ ПРОГРАММ ВСПОМОГАТЕЛЬНЫХ РЕПРОДУКТИВНЫХ ТЕХНОЛОГИЙ У ЖЕНЩИН С РАЗНЫМИ ФОРМАМИ БЕСПЛОДИЯ

Цель исследования - анализ эффективности применения различных программ вспомогательных репродуктивных технологий (ВРТ) у женщин с разными фрормами бесплодия по результатам ретроспективного анализа медицинской документации.

Материалы и методы. Проведено исследование эфффективности программ ВРТ путем ретроспективного анализа причины и структуры бесплодия, применения различных методик ВРТ, наступления беременности и родов у женщин с разными формами бесплодия, в частности плохих ответчиков, в период 2013-2016 годов.

Результаты исследования и их обсуждение. Доказано, что количество женщин с разными формами бесплодия и, соответственно, циклов ВРТ неуклонно растет. Отмечено увеличение частоты как женского, так и мужского бесплодия с приблизительно одинаковым процентным соотношением, наблюдается рост женщин с бесплодием старшей возрастной категории. При этом, несмотря на развитие и применение программ ВРТ, особенно у женщин старшей возрастной группы, количество диагностируемых клинических беременностей существенно не отличается за период 2013-2016 годов.

Вывод. Представленные результаты исследования доказывают, что вероятность наступления беременности имеет обратную связь с возрастом женщины и ее овариальным резервом, что может быть предиктором низкого овариального ответа на контролируемую стимуляцию яичников в программах ВРТ.
\end{abstract}

Ключевые слова: бесплодие; программы ВРТ; «плохие ответчики»; возраст.

RETROSPECTIVE ANALYSIS OF THE EFFECTIVENESS OF ART PROGRAMS IN WOMEN WITH DIFFERENT FORMS OF INFERTILITY

The aim of the study - analysis of the effectiveness of the use of different programs of ART in women with various forms of infertility according to a retrospective analysis of medical records.

Materials and Methods. The effectiveness of ART programs has been conducted through a retrospective analysis of the cause and structure of infertility, the use of different methods of ART, the onset of pregnancy and childbirth in women with various forms of infertility, including poor responders during 2013-2016.

Results and Discussion. It is proved that the number of women with different forms of infertility and, accordingly, ART cycles is growing steadily. There was an increase in the frequency of both female and male infertility with approximately the same percentage, an increase in women with infertility of the older age category was observed. Moreover, despite the development and application of ART programs especially for women of the older age group, the number of diagnosed clinical pregnancies does not differ significantly for the period 2013-2016. 
Conclusion. The results of the study show that the likelihood of pregnancy has an inverse relationship with a woman's age and her ovarian reserve, which may be a predictor of low ovarian response to controlled ovarian stimulation in ART programs.

Key words: infertility; ART programs; "poor responders"; age.

ВстУП. Фертильність людей в усьому світі зазнає дуже суттєвих змін в останні десятиліття. I хоча ситуація відрізняється в різних регіонах, країнах, релігійних спільнотах, глобальна тенденція полягає в зниженні народжуваності. Так, згідно з даних World Fertility Pattern, 2015, загальносвітова середня кількість дітей на 1 жінку складає 2,5. Треба відзначити, що для Східної Європи та для України характерні значно нижчі показники - в межах 1,6-1,7. Сьогодні $46 \%$ населення світу живе в країнах із низьким рівнем народжуваності, де у жінок менше 2,1 дітей у середньому. Країни з низьким рівнем народжуваності зараз включають всю Європу та Північну Америку, а також багато країн Азії, Латинської Америки та Карибського бассейну.

ще однією з основних тенденцій сучасного західного суспільства $є$ поступове та постійне збільшення віку вступу в шлюб та народження дітей. Це спостерігається не тільки в Україні, але й в інших європейських країнах. За останні 40 років середній вік жінок, які вступають у шлюб, збільшився в країнах Європи більш ніж на 2,5 року. Як і в інших країнах Європи, в Україні підвищуються вікові показники укладання шлюбу: середній вік вступу до шлюбу чоловіків за 1989-2007 рр. підвищився з 26,8 до 29,6 року (до першого шлюбу - $з$ 23,9 до 26,0); жінок, відповідно, 3 25,3 до 26,8 (до першого шлюбу - з 21,9 до 23,5). Відповідні зміни відбуваються і в розподілі шлюбів за віком наречених. Зменшується частка ранніх шлюбів у їх загальній кількості. Якщо в 1989 р. у 20,2 \% укладених шлюбів (у тому числі у 26,6 \% перших шлюбів) наречена була віком до 19 років, то у 2007 р., відповідно, у 8,5 і 10,9\%. Водночас збільшується частка шлюбів, укладених після 30 років.

Питання подолання безпліддя є дуже актуальною проблемою, незважаючи на значне поширення ДРТ у клінічній практиці, і особливо, питання подолання безпліддя у жінок старшого віку. Має місце тенденція до збільшення серед жінок із безпліддям «поганих відповідачів» на контрольовану стимуляцію яєчників, що пов'язано як із збільшенням віку пацієнток, так і $з$ певною низкою набутих чинників, що зумовлює фрізіологічне та патологічне згасання фрертильної фрункції і зменшення оваріального резерву та ускладнює реалізацію програм ДРТ.

Отже, демографрічна ситуація в Україні вимагає удосконалення нових методів лікування безпліддя, а частка жінок пізнього репродуктивного віку в структурі всіх пацієнток із безпліддям буде тільки збільшуватись, що значно ускладнює реалізацію репродуктивних планів порівняно з молодими жінками.

МЕТА ДОСЛІДЖЕННЯ - ретроспективний аналіз медичної документації жінок із різними формами безпліддя, які перебували на обстеженні та лікуванні в медичному центрі «Родинне джерело» за період 2013-2016 років для оцінки есрективності застосування програм ДРТ.

МАТЕРІАЛИ ТА МЕТОДИ. ДЛЯ оцінкИ ефектИвності лікування безпліддя за допомогою ДРТ, а також для встановлення причин невдалих циклів ЕКЗ було проведено ретроспективний аналіз амбулаторних карт 725 пацієнток, залучених в програми ДРТ, за період з 2013 до 2016 рік у клініці «Родинне джерело» м. Києва. За допо- могою спеціально розробленої анкети шляхом вивчення причини та структури безпліддя, застосування різних методів ДРТ протягом звітного періоду проводили аналіз настання вагітності та пологів у жінок із різними формами безпліддя, зокрема «поганих відповідачів».

РЕЗУЛЬТАТИ ДОСЛІДЖЕННЯ ТА ЇХ ОБГОВОРЕННЯ. Так, кількість розпочатих лікувальних циклів, протягом яких передбачалося проведення лікування безпліддя методами допоміжних репродуктивних технологій, значно зросла протягом звітного періоду. Якщо в 2013 році кількість жінок, які звернулися за допомогою, склала 102 пацієнтки $з$ кількістю розпочатих циклів 124, то в 2016 році цей показник був 249 пацієнток, у яких розпочато 306 лікувальних циклів з поступовим зростанням в 2014 та 2015 роках - 167 пацієнток (203 лікувальних цикли) та 207 пацієнток (252 лікувальні цикли) відповідно (рис. 1).

За даними статистичних звітів, що виконуються в клініці, з 2013 до 2016 року спостерігається зростання частоти як жіночого, так і чоловічого безпліддя з приблизно однаковим відсотковим співвідношенням, однак з перевагою жіночого в 3,3 раза. Так, якщо частка жіночого безпліддя як у 2013, так і в 2016 роках стосовно інших видів безпліддя була відносно сталою та складала в 2013 році 54 (52,9\%), в 2016 році - 112 (44,9\%), то кількість чоловічого безпліддя статистично вірогідно збільшилася та склала в 2013 році 9 (8,8 \%) та в 2016 році - 34 (13,6 \%). Також має місце зростання випадків сполученого безпліддя (жіночий та чоловічий чинник) - в 2013 році 31 (30,4\%) випадок проти 81 (32,5 \%) в 2016 році (табл. 1).

Серед причин жіночого безпліддя має місце деяка зміна структури нозологій. Щодо кількості трубно-перитонеального безпліддя, то його частка серед причин звернень до клініки ДРТ майже не змінилася - 47 (46,1 \%) випадків у 2013 році проти 123 (49,4 \%) в 2016 році з деяким коливанням показників у 2014 та 2015 роках - 79 (47,3 \%) та 102 (49,2 \%) відповідно. Має місце статистично вірогідна різниця реєстрації випадків різних орорм ендометріозу як причини безпліддя. Якщо в 2013 році кількість діагностованого генітального ендометріозу у жінок із безпліддям склала 23 (22,5\%), в 2014 році - 47 (28,1\%), то в 2015 та 2016 роках - 72 (34,7 \%) та 89 (35,7 \%) відповідно. При цьому спостерігається зменшення випадків синдрому полікістозних яєчників (СПКЯ) як причини безпліддя: в 2013 році - 29 (28,5 \%), в 2014 році - 18 (107\%), в 2015 році - 23 (11,1 \%) та в 2016 році 29 (11,6 \%) (табл. 2).

У структурі розпочатих циклів за звітний період має місце значне зростання кількості циклів ЕКЗ/ІКСІ (інтраплазматичне введення сперматозоїдів): 2013 рік - 57 (45,8 \%) випадків, 2014 рік - 131 (64,5 \%), 2015 рік - 188 (74,7 \%), 2016 рік - 248 (81,1 \%) та циклів із перенесенням кріоконсервованих ембріонів: 2013 рік - 19 (15,3\%), 2014 рік - 40 (19,7\%), 2015 рік - 65 (25,7\%) та 2016 рік - 95 (31,0 \%). Також тенденцію до зростання мають цикли 3 донацією ооцитів та цикли 3 передімплантаційною генетичною діагностикою (ПГД). Якщо в 2013 році кількість циклів із донацією склала 6 (4,8 \%) випадків, то в 2016 році - 58 (18,9\%), циклів із ПГД в 2013 році було 
зареєстровано 2 (1,6 \%), в 2016 році - 28 (9,2 \%). Щодо проведення циклів із заплідненням ооцитів сперматозоїдами шляхом інсемінації (IVF), то їх кількість значно зменшилася з 2013 до 2016 року - 67 (54,2 \%) в 2013 році проти 58 (18,9\%) в 2016 році (табл. 3).

Цікавим виявився аналіз структури розпочатих лікувальних циклів за методами ДРТ залежно від чинника безпліддя, дані про що наведені в таблиці 4.

Аналізуючи показники таблиці 4, відзначено значне збільшення циклів із застосуванням методики ICSI у ви- падках суто жіночого безпліддя - 16/25,0 \% в 2013 році проти 106/79,2 \% в 2016 році, зменшення кількості циклів IVF при всіх фрормах безпліддя - 42/65,6 \% випадків при жіночому безплідді, 8/42,1 \% випадків при чоловічому безплідді, 10/27,0 \% - при сполучених чинниках в 2013 році проти 28/20,8 \% випадків застосування цієї методики при жіночому безплідді, 3/7,5 \% - при чоловічому, 12/12,3 \% - при сполучених чинниках та 2/5,7 \% при ідіопатичному безплідді в 2016 році. Крім цього, звертає на себе увагу значне збільшення кількості випадків з використанням

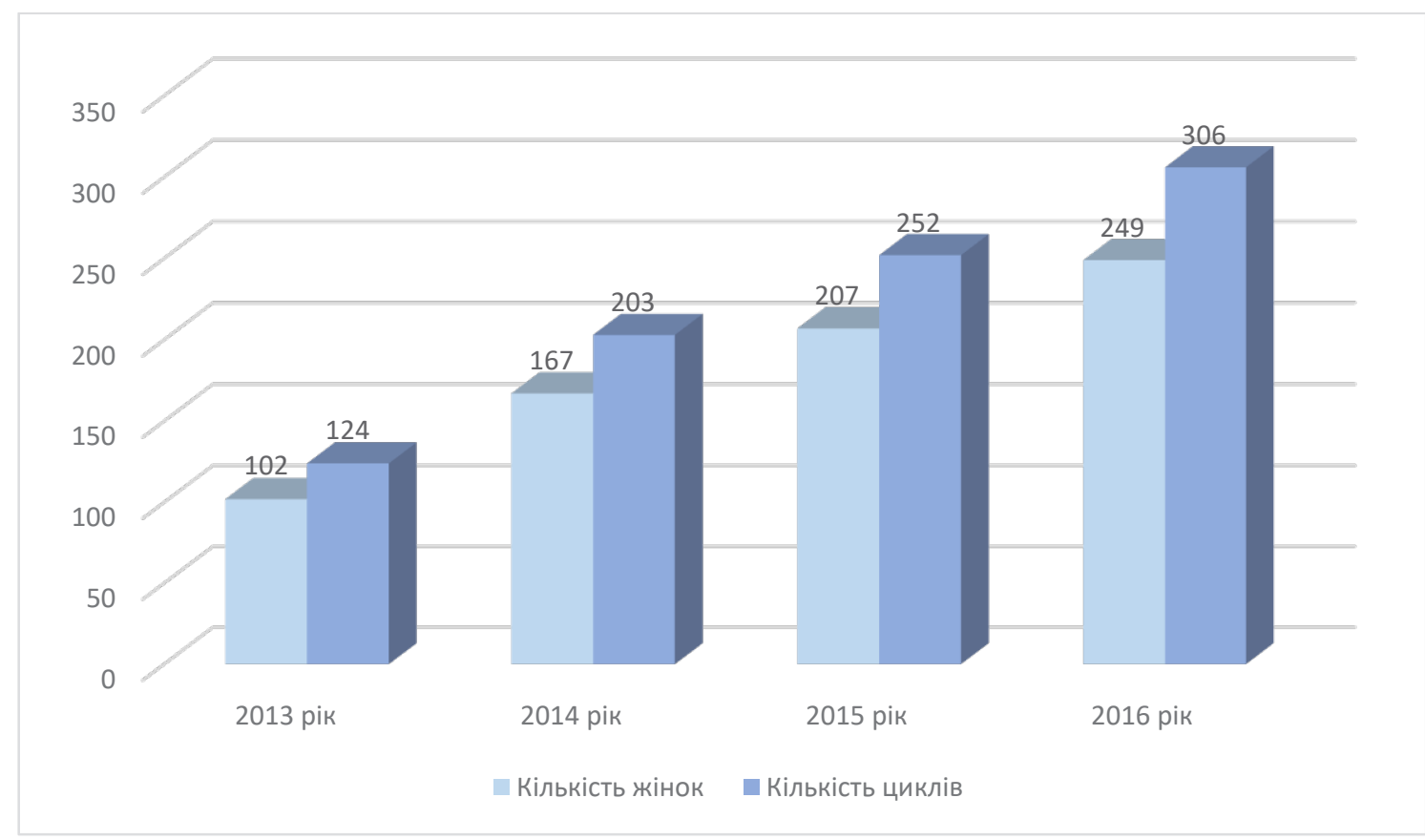

Рис. 1. Кількість проведених циклів ДРТ за даними ретроспективного аналізу 2013-2016 років (n=725).

Таблиця 1. Причини безпліддя за даними ретроспективного аналізу 2013-2016 років (абс.ч./ \%)

\begin{tabular}{||l|c|c|c|c||}
\hline \multirow{2}{*}{$\begin{array}{c}\text { чинник } \\
\text { безпліддя }\end{array}$} & 2013 рік & 2014 рік & 2015 рік & 2016 рік \\
\cline { 2 - 5 } & $\mathrm{n}=102$ & $\mathrm{n}=167$ & $\mathrm{n}=207$ & $\mathrm{n}=249$ \\
\hline Жіночий & $54 / 52,9$ & $83 / 49,7$ & $97 / 46,8$ & $34 / 44,9$ \\
\hline Чоловічий & $9 / 8,8^{*}$ & $9 / 11,4$ & $26 / 12,6$ & $81 / 32,5$ \\
\hline Сполучений & $31 / 30,4^{*}$ & $49 / 29,3$ & $65 / 31,4$ & $22 / 9,0$ \\
\hline Ідіопатичний & $8 / 7,9$ & $26 / 9,6$ & $19 / 9,2$ & \\
\hline
\end{tabular}

Примітка. * - 2013 рік/2016 рік $(\mathrm{p}<0,05)$.

Таблиця 2. Структура жіночого фактора безпліддя за даними ретроспективного аналізу 2013-2016 років (абс. ч./ \%)

\begin{tabular}{||l|c|c|c|c||}
\hline \multirow{2}{*}{$\begin{array}{c}\text { Чинник } \\
\text { безпліддя }\end{array}$} & 2013 рік & 2014 рік & 2015 рік & 2016 рік \\
\cline { 2 - 5 } & $\mathrm{n}=102$ & $\mathrm{n}=167$ & $\mathrm{n}=207$ & $\mathrm{n}=249$ \\
\hline Трубно-перитонеальний & $47 / 46,1$ & $79 / 47,3$ & $102 / 49,2$ & $123 / 49,4$ \\
\hline Ендометріоз & $23 / 22,5^{*}$ & $47 / 28,1$ & $72 / 34,7$ & $89 / 35,7$ \\
\hline Спкя & $29 / 28,5^{*}$ & $18 / 10,7$ & $23 / 11,1$ & $29 / 11,6$ \\
\hline Ідіопатичний & $3 / 2,9$ & $23 / 13,9$ & $10 / 5,0$ & $8 / 3,3$ \\
\hline
\end{tabular}

Примітка. * - 2013 рік/2016 рік $(\mathrm{p}<0,05)$. 
Акушерство та гінекологія

Таблиця 3. Розподіл циклів за методом ДРТ за даними ретроспективного аналізу 2013-2016 років (абс.ч./ \%)

\begin{tabular}{||l|l|l|l|l|l|l|l||}
\hline \hline Роки & \multicolumn{1}{|c|}{ Всього циклів } & \multicolumn{1}{|c|}{ IVF } & \multicolumn{1}{|c|}{ ICSI } & \multicolumn{1}{|c|}{ TESE } & \multicolumn{1}{|c|}{ Донація ооцитів } & \multicolumn{1}{|c|}{ Кріо ЕT } & \multicolumn{1}{c|}{ ПГД } \\
\hline 2013 & 124 & $67 / 54,2^{*}$ & $57 / 45,8^{*}$ & $2 / 1,6$ & $6 / 4,8^{*}$ & $19 / 15,3^{*}$ & $2^{2 / 1,6^{*}}$ \\
\hline 2014 & 203 & $72 / 35,5$ & $131 / 64,5$ & $3 / 1,5$ & $19 / 9,4$ & $40 / 19,7$ & $2 / 0,9$ \\
\hline 2015 & 252 & $64 / 25,3$ & $188 / 74,7$ & $8 / 3,1$ & $39 / 15,5$ & $65 / 25,7$ & $9 / 3,6$ \\
\hline 2016 & 306 & $58 / 18,9$ & $248 / 81,1$ & $11 / 3,5$ & $58 / 18,9$ & $95 / 31,0$ & $28 / 9,2$ \\
\hline
\end{tabular}

Примітка. * - 2013 рік/2016 рік $(p<0,05)$.

Таблиця 4. Структура розпочатих лікувальних циклів за методами ДРТ залежно від чинника безпліддя за 2013, 2016 роки (абс.ч./ \%)

\begin{tabular}{|c|c|c|c|c|c|c|c|c|}
\hline \multirow[b]{2}{*}{$\begin{array}{c}\text { Чинник } \\
\text { безпліддя }\end{array}$} & \multicolumn{4}{|c|}{2013 рік (n=102, кількість циклів 124) } & \multicolumn{4}{|c|}{2016 рік (n=249, кількість циклів 306) } \\
\hline & $\begin{array}{c}\text { жіноче } \\
\text { безпліддя } \\
(\mathrm{n}=54, \\
\text { кількість } \\
\text { циклів - 64) } \\
\end{array}$ & $\begin{array}{c}\text { чоловіче } \\
\text { безпліддя } \\
(n=9, \\
\text { кількість } \\
\text { циклів - 19) }\end{array}$ & $\begin{array}{c}\text { сполучене } \\
\text { безпліддя } \\
(\mathrm{n}=31, \\
\text { кількість } \\
\text { циклів - 37) }\end{array}$ & $\begin{array}{c}\text { ідіопатичне } \\
\text { безпліддя } \\
(n=3, \\
\text { кількість } \\
\text { циклів - 4) } \\
\end{array}$ & $\begin{array}{c}\text { жіноче } \\
\text { безпліддя } \\
\text { (n=112, } \\
\text { кількість } \\
\text { циклів - 134) }\end{array}$ & $\begin{array}{c}\text { чоловіче } \\
\text { безпліддя } \\
(n=34, \\
\text { кількість } \\
\text { циклів - 40) }\end{array}$ & $\begin{array}{c}\text { сполучене } \\
\text { безпліддя } \\
(\mathrm{n}=81, \\
\text { кількість } \\
\text { циклів - 97) }\end{array}$ & $\begin{array}{c}\text { ідіопатичне } \\
\text { безпліддя } \\
(n=22, \\
\text { кількість } \\
\text { циклів - 35) }\end{array}$ \\
\hline IVF & $42 / 65,6$ & $8 / 42,1$ & $10 / 27,0$ & $2 / 50,0$ & $28 / 20,8$ & $3 / 7,5$ & $12 / 12,3$ & $2 / 5,7$ \\
\hline ICSI & $19 / 29,6$ & $11 / 57,8$ & $27 / 72,9$ & - & $106 / 79,2$ & 28/925 & $85 / 87,7$ & $33 / 94,3$ \\
\hline MESE-TESE & - & $2 / 10,5$ & - & - & - & $6 / 15,0$ & $5 / 5,2$ & - \\
\hline $\begin{array}{l}\text { Донація } \\
\text { ооцитів }\end{array}$ & $4 / 6,2$ & - & $2 / 5,4$ & - & $18 / 13,4$ & $10 / 25,0$ & $22 / 22,6$ & $5 / 14,2$ \\
\hline Kpio-ET & $10 / 15,7$ & $2 / 10,5$ & $2 / 5,4$ & $2 / 50,0$ & $16 / 11,9$ & $12 / 30,0$ & $62 / 63,9$ & $10 / 28,5$ \\
\hline ПгД & - & - & $2 / 5,4$ & - & $8 / 6,1$ & - & $5 / 5,2$ & $15 / 43,1$ \\
\hline
\end{tabular}

донорських ооцитів при всіх видах безпліддя в 2016 році: 18/13,4 \% при жіночому безплідді, 10/25,0 \% - при чоловічому безплідді, 22/22,6 \% - при сполучених чинниках та 5/14,2 \% - при ідіопатичному безплідді, тоді як в 2013 році використання донорських яйцеклітин мало місце в 4/6,2 \% випадках при жіночому безплідді та в 2/5,4 \% - при сполучених чинниках безпліддя. Також спостерігається значне збільшення кількості циклів з переносом заморожених ембіронів при всіх формах безпліддя за 2013-2016 роки та циклів із ПГД, яких у 2013 році зафріксовано лише 2/5,4 \% випадків при сполучених чинниках проти 15/43,1\% випадків при ідіопатичному безплідді, 5/5,2 \% випадків при сполучених чинниках та 8/6,1 \% при жіночому безплідді в 2016 році.

щодо вікового розподілу, то протягом періоду 20132016 років мають місце статистично вірогідні відмінності середнього віку жінок, які зверталися в клініку ДРТ 3 приводу лікування безпліддя. Так, має місце невпинне зростання жінок із безпліддям старшої вікової категорії. Якщо в 2013 році пацієнток, старших 40 років, було 18 (17,6 \%), то в 2016 році їх кількість становила 73 (29,3\%), така ж тенденція спостерігається у віковій категорії 35-39 років - $28(27,4 \%)$ у 2013 році проти 79 (31,7\%) жінок у 2016 році. Пацієнток віком 30-34 роки та менше 25 років була приблизно однакова кількість: 32 (31,1 \%) та 3 (2,9\%), відповідно, в 2013 році проти 81 (32,5\%) та 7 (2,8 \%), відповідно, в 2016 році. Щодо жінок віком 25-29 років, то їх кількість з роками статистично вірогідно зменшувалась - $21(20,7 \%)$ в 2013 році, $26(15,6 \%)$ в 2014 році, 16 (7,7\%) в 2015 році та 9 (3,7\%) в 2016 році (рис. 2).
Характеристика розпочатих лікувальних циклів за методами допоміжних репродуктивних технологій відповідно до віку наведена в таблиці 5.

Звертають на себе увагу зміни структури застосування різних методів ДРТ у жінок в різні вікові категорії в 2013, 2016 роках. Так, у 2016 році має місце збільшення застосування методики ICSI, особливо у віці 35-39 років та у жінок, старших 40 років, - 60/75,9 \% та 69/94,6 \% відповідно проти 21/75,0 \% та 16/88,9 \% відповідно в 2013 році. Така ж тенденція спостерігається щодо донації ооцитів, якщо в 2013 році у жінок віком 35-39 років така методика застосовувалась в 9/32,1 \% випадків, у віці більше 40 років - у 10/35,7 \%, то в 2016 році ці показники становили 33/41,7 \% та 43/58,9 \% відповідно. Збільшилася кількість передімплантаційної генетичної діагностики ембріонів у жінок старшої вікової категорії в 2016 році: 11/13,9 \% у віці 35-39 років, 17/23,3 \% у віці більше 40 років проти 2/7,0 \% випадків у віці більше 40 років у 2013 році.

Аналізуючи настання вагітності у жінок із безпліддям після застосування методик ДРТ, встановлено, що кількість лікувальних циклів, які закінчилися клінічною вагітністю, щорічно збільшується. Так, у 2013 році кількість клінічних вагітностей на 100 розпочатих циклів становила 35,82, в 2014 році - 37,3, в 2015 році - 36,56 та в 2016 році $-37,64$ (рис. 3).

Щодо закінчення клінічних вагітностей на 100 лікувальних циклів, то в 2013 році ектопічною вагітністю закінчилися 0,47 циклів, в 2014 році - 0,48, в 2015 році - 0,38 та в 2016 році - 0,30 циклів, спонтанним абортом 


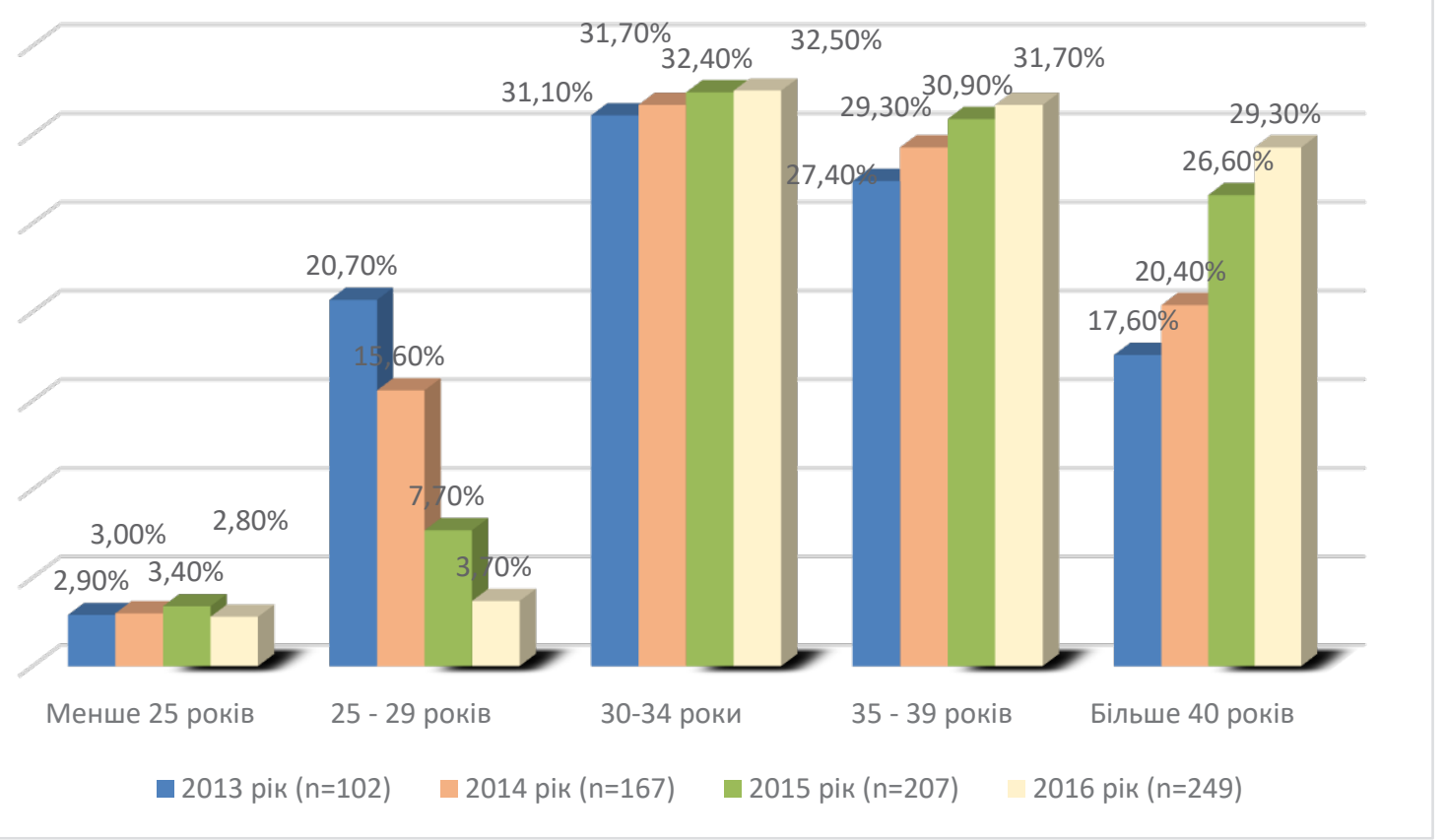

Рис. 2. Віковий розподіл жінок із безпліддям за 2013-2016 роки.

Таблиця 5. Структура розпочатих лікувальних циклів за методами ДРТ залежно від віку пацієнток за 2013, 2016 роки (абс.ч.l \%)

\begin{tabular}{||l|c|c|c|c|c|c|c|c||}
\hline \multirow{2}{*}{$\begin{array}{c}\text { Методика } \\
\text { ДРТ }\end{array}$} & $\begin{array}{c}\text { до } 29 \\
\text { років } \\
(\mathrm{n}=24)\end{array}$ & $\begin{array}{c}30-34 \\
\text { роки } \\
(\mathrm{n}=32)\end{array}$ & $\begin{array}{c}35-39 \\
\text { років } \\
(\mathrm{n}=28)\end{array}$ & $\begin{array}{c}\text { більше } 40 \\
\text { років } \\
(\mathrm{n}=18)\end{array}$ & $\begin{array}{c}\text { до 29 } \\
\text { років } \\
(\mathrm{n}=16)\end{array}$ & $\begin{array}{c}30-34 \\
\text { роки } \\
(\mathrm{n}=81)\end{array}$ & $\begin{array}{c}35-39 \\
\text { років } \\
(\mathrm{n}=79)\end{array}$ & $\begin{array}{c}\text { більше } \\
40 \text { років } \\
(\mathrm{n}=73)\end{array}$ \\
\hline IVF & $15 / 62,5$ & $9 / 28,1$ & $7 / 25,0$ & $2 / 11,1$ & $11 / 68,7$ & $24 / 29,6$ & $19 / 24,1$ & $4 / 5,4$ \\
\hline ICSI & $11 / 37,5$ & $23 / 71,9$ & $21 / 75,0$ & $16 / 88,9$ & $5 / 31,3$ & $57 / 70,4$ & $60 / 75,9$ & $69 / 94,6$ \\
\hline МЕSE-TESE & - & - & $1 / 3,5$ & $1 / 3,5$ & - & - & $4 / 5,1$ & $7 / 9,5$ \\
\hline $\begin{array}{l}\text { Донація } \\
\text { ооцитів }\end{array}$ & $1 / 4,2$ & $1 / 3,1$ & $9 / 32,1$ & $10 / 35,7$ & $1 / 6,2$ & $2 / 2,5$ & $33 / 41,7$ & $43 / 58,9$ \\
\hline Кріо-ЕТ & $9 / 37,5$ & $14 / 43,9$ & $8 / 28,6$ & $9 / 50,0$ & $1 / 6,2$ & $21 / 25,9$ & $58 / 73,4$ & $57 / 78,1$ \\
\hline ПГД & - & - & - & $2 / 7,0$ & - & - & $11 / 13,9$ & $17 / 23,3$ \\
\hline
\end{tabular}

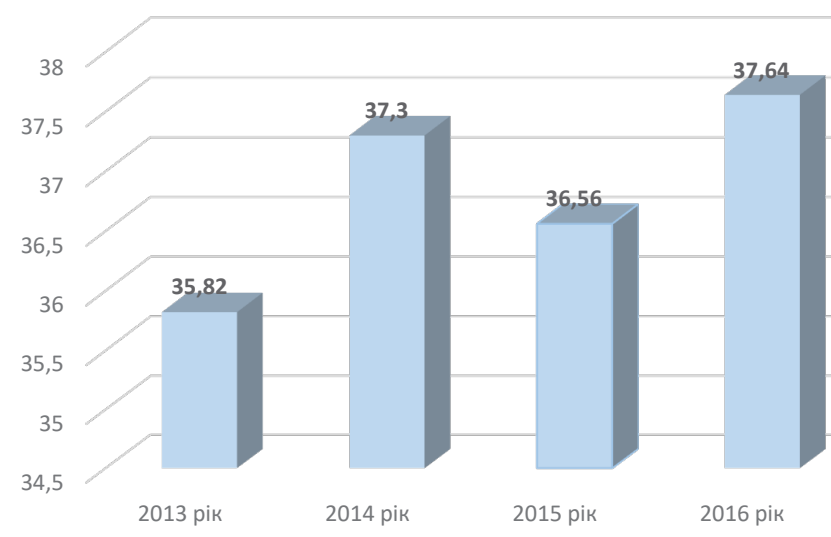

Рис. 3. Частота клінічних вагітностей на 100 розпочатих циклів за 2013-2016 роки. закінчилися 4,88 циклів у 2013 році, 5,18 циклів у 2014 році, 4,45 - в 2015 році та 4,38 - в 2016 році. Пологи одним живим плодом відбулися в 20,56 циклів у 2013 році, 21,12 циклів у 2014 році, 23,84 циклів у 2015 році та 24,35 циклів у 2016 році. Пологи двома та більше плодами відбулися в 2013 році в 7,01 циклів, в 2014 році - в 7,47 циклів, в 2015 році - в 5,73 циклів та в 2016 році - в 6,82 циклів (рис. 4).

В абсолютних числах кількість вагітностей, які закінчилися народженням одного та двох живих дітей, у 2013 році становила 34, в 2014 році - 57, в 2015 році - 69 та в 2016 році - 96.

Цікавим виявився аналіз структури вагітностей, які закінчилися народженням живих дітей, за віковою категорією (рис. 5).

Так, найбільша кількість народжених дітей мала місце у віковій категорії 25-29 років та 30-34 роки. У 2013 році 


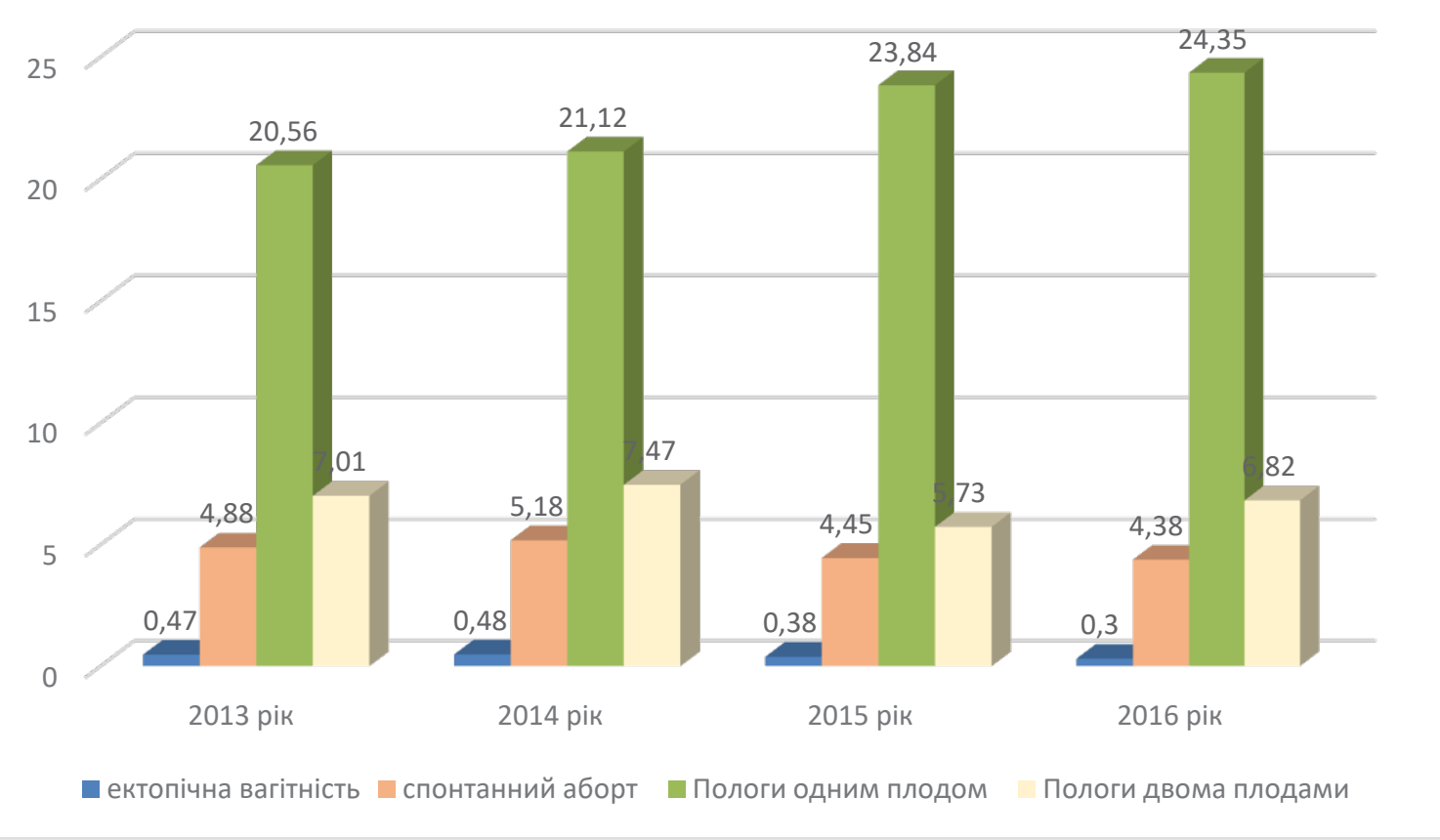

Рис. 4. Результат клінічних вагітностей при розпочатих лікувальних циклах за 2013-2016 роки.

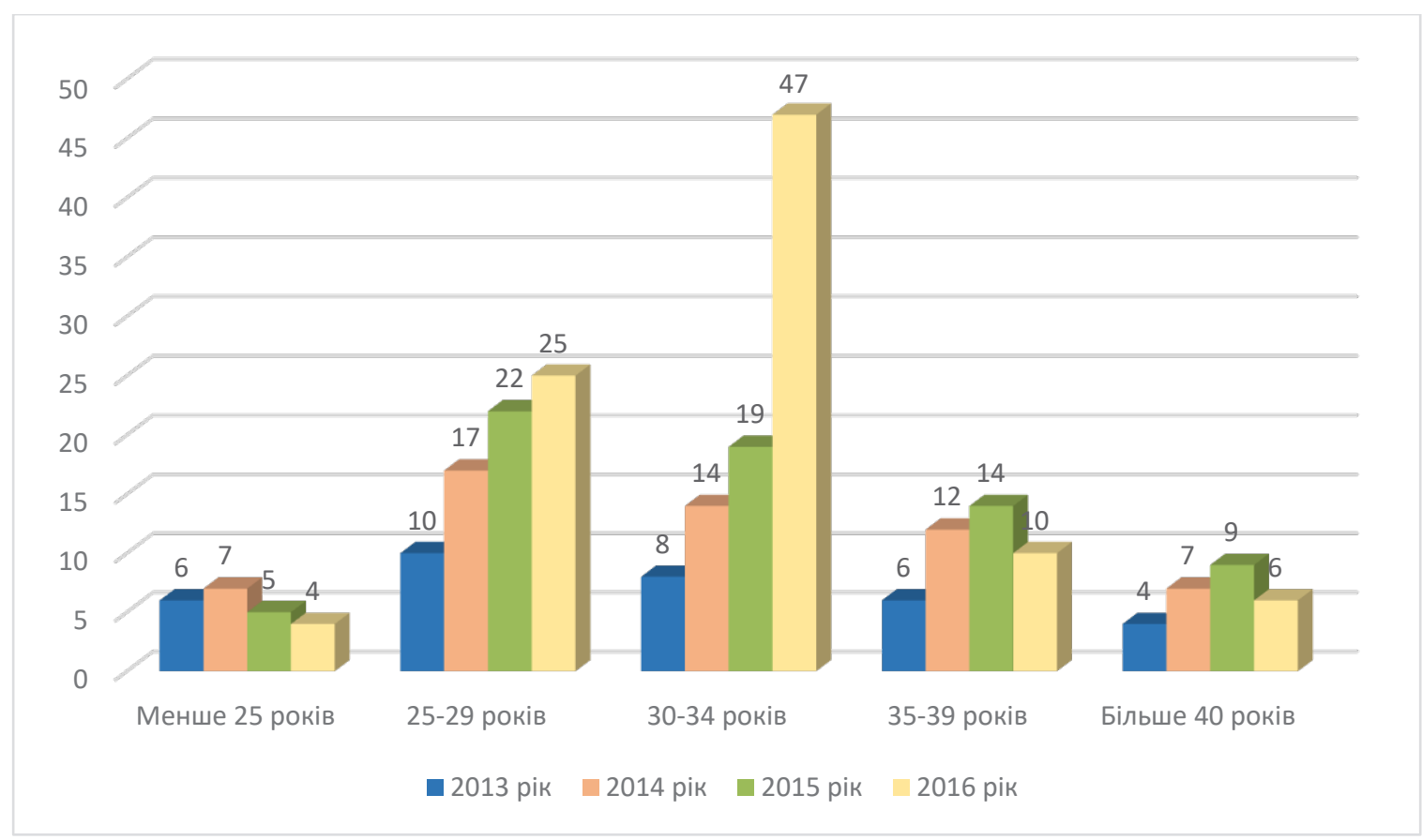

Рис. 5. Кількість народжених дітей у жінок із безпліддям після застосування ДРТ залежно від вікової категорії.

їх кількість була 10 та 8 відповідно, в 2014 році - 17 та 14 відповідно, в 2015 році - 22 та 19 відповідно, в 2016 році - 25 та 47 відповідно. Незмінною є мала кількість дітей, які народжуються у жінок старшої вікової групи протягом звітного періоду. Так, у 2013 році у жінок віком 35 - більше 40 років народилося лише 10 дітей, в 2014 році - 19 дітей, в 2015 році - 23 дитини та в 2016 році
- 16 дітей. Підсумовуючи дані ретроспективного аналізу застосування допоміжних репродуктивних технологій у лікуванні безпліддя в клініці «Родинне джерело» за 2013-2014 роки, можна зробити такі висновки.

висновкИ. 1. Кількість жінок та, відповідно, циклів ДРТ невпинно зростає протягом звітного періоду, що свідчить про актуальність проблеми безпліддя в сучас- 
ній гінекології - кількість розпочатих циклів у 2013 році становила 124, тоді як в 2016 році вже 306.

2. На фроні зростання частоти як жіночого, так і чоловічого безпліддя 3 приблизно однаковим відсотковим співвідношенням 3 перевагою жіночого в 3,3 раза, дещо змінилася структура суто жіночого безпліддя, де на перший план в 2016 році виходить трубно-перитонеальний фактор - 123/49,4 \% та ендометріоз - 89/35,7 \%, тоді як у 2013 році поряд з трубно-перитонеальним фрактором $47 / 46,1$ \% вагоме значення мав СПКя - 29/28,5 \%.

3. Протягом звітного періоду спостерігається невпинне зростання жінок із безпліддям старшої вікової категорії, а саме віком 35-39 років, кількість яких в 2013 році становила 28 (27,4 \%) пацієнток, тоді як в 2016 році вже 79 (31,7 \%). У віці понад 40 років у 2013 році за допомогою звернулися 18 (17,6 \%) жінок, в 2016 році - 73 (29,3 \%) пацієнтки.

4. Незважаючи на розвиток програм допоміжних репродуктивних технологій та збільшення використання з 2013 по 2016 рік таких методик, як ICSI (57/45,8 \% та 248/81,1 \% відповідно), донація ооцитів (6/4,8 \% та 58/18,9 \% відповідно), циклів з переносом заморожених ембріонів (19/15,3 \% та 95/31,0 \% відповідно) та проведення ПГД ембріонів (2/1,6 \% та 28/9,2 \% відповідно), особливо у жінок старшої вікової групи, кількість діагностованих клінічних вагітностей у жінок віком 35 - понад 40 років суттєво не відрізняється протягом 2013-2016 років. Вірогідність настання вагітності має зворотний зв'язок із віком жінки та її оваріальним резервом, що може бути предиктором низької оваріальної відповіді на контрольовану стимуляцію яєчників.

ПЕРСПЕКТИВИ ПОДАЛЬШИХ ДОСЛІДЖЕНЬ. ВИЩЕнаведений фракт спонукає до ретельного вивчення фракторів ризику, етіології та патогенезу виникнення безпліддя у жінок із зниженим оваріальним резервом, які складають групу «поганих відповідачів», із подальшою розробкою індивідуальних діагностично-лікувальних алгоритмів для підвищення відповіді яєчників у програмах контрольованої стимуляції, що дозволить підвищити ефективність досягнення вагітності у пацієнток даної категорії.

\section{СПИСОК ЛІТЕРАТУРИ}

1. Александрова Н. В. Современные подходы к оценке овариального резерва у женщин с преждевременной недостаточностью яичников / Н. В. Александрова, Л. А. Марченко // Проблемы репродукции. - 2007. - № 2. - С. 22-29.

2. Данкович Н. А. Причины и фоормы бесплодия. Современные возможности диагностики и лечения / Н. А. Данкович, В. Н. Воробей-Виховская // Здоровье женщины. - 2013. - № 3. - С. 192-197.

3. Маслій Ю. В. Етіопатогенетичні чинники синдрому слабкої відповіді яєчників в циклах допоміжних репродуктивних технологій / Ю. В. Маслій, І. О. Судома, Г. Б. Лівшиць // Здоровье женщины. - 2006. - № 4 (28). - С. 152-157.

4. Мишиева Н. Г. Бесплодие у женщин позднего репродуктивного возраста: принципы диагностики и лечения в зависимости от овариального резерва : дис. ... д-ра мед. наук : 14.00.01 / Н. Г. Мишиева. - М., 2010. - 272 с.

5. Юзько О. М. Стан та перспективи використання допоміжних репродуктивних технологій при лікуванні безпліддя в Україні / О. М. Юзько, Т. А. Юзько, Н. Г. Руденко // Здоровье женщины. - 2013. - № 8. - С. 26-30.

6. Rate of severe ovarian damage following surgery for endometriomas / L. Benaglia, E. Somigliana, V. Vighi [et al.]. Human Reproduction. - 2010. - Vol. 25, No. 3. - P. 678-682.

7. Combined gonadotropin releasing hormone agonist/ human menopausal gonadotropin therapy ( $\mathrm{GnRH}-\mathrm{a} / \mathrm{hMG})$ in normal, high, and poor responders to hMG / Z. Ben-Rafael, D. Bider, U. Dan [et al.] // Journal of In Vitro Fertilization and Embryo Transfer. - 1991. - Vol. 8, No. 1. - P. 33-36.

8. Accelerated disappearance of ovarian follicles in midlife: implications for forecasting menopause / M. J. Faddy, R. G. Gosden, A. Gougeon [et al.] // Human Reproduction. -

\section{REFERENCES}

1. Aleksandrova, N.V., \& Marchenko, L.A. (2007). Sovremennyye podkhody $k$ otsenke ovarialnogo rezerva u zhenshchin s prezhdevremennoy nedostatochnostyu yaichnikov [Modern approaches to the assessment of ovarian reserve in women with premature ovarian failure]. Problemy reproduktsii-Problems of Reproduction, 2, 22-29 [in Russian].
1992. - Vol. 7, no. 10. - P. 1342-1346.

9. ESHRE consensus on the definition of "poor response" to ovarian stimulation for in vitro fertilization: the Bologna criteria / A. P. Ferraretti, A. B. La Marca, C. J. M. Fauser [et al.] // Human Reproduction. - 2011. - Vol. 26, No. 7. - P. 1616-1624.

10. Comparison of "poor" responders with "good" responders using a standard buserelin/human menopausal gonadotrophin regime for in-vitro fertilization / J. M. Jenkins, D. W. Davies, H. Devonport [et al.] // Human Reproduction. - 1991. - Vol. 6, No. 7. - P. 918-921.

11. Assisted conception following poor ovarian response to gonadotrophin stimulation / S. D. Keay, N. H. Liversedge, R. S. Mathur, J. M. Jenkins // The British Journal of Obstetrics and Gynaecology. - 1997. - Vol. 104, No. 5. - P. 521-527.

12. Addition of growth hormone to gonadotrophins in ovarian stimulation of poor responders treated by in-vitro fertilization: a systematic review and meta-analysis / E. M. Kolibianakis, C. A. Venetis, K. Diedrich [et al.] // Human Reproduction Update. - 2009. - Vol. 15, No. 6. - P. 613-622.

13. Polyzos N. P. A systematic review of randomized trials for the treatment of poor ovarian responders: is there any light at the end of the tunnel / N. P. Polyzos, P. Devroey // Fertility and Sterility. - 2011. - Vol. 96, No. 5. - P. 1058-1061.

14. Surrey E. S. Evaluating strategies for improving ovarian response of the poor responder undergoing assisted reproductive techniques / E. S. Surrey, W. B. Schoolcraft // Fertility and Sterility. - 2000. - Vol. 73, No. 4. - P. 667-676.

15. Ziegler D. Endometriosis and infertility: pathophysiology and management / D. Ziegler, B. Borghese, C. Chapron // The Lancet. - 2010. - Vol. 376, No. 9742. - P. 730-738.

2. Dankovich, N.A., \& Vorobey-Vikhovskaya, V.N. (2013). Prichiny i formy besplodiya. Sovremennyye vozmozhnosti diagnostiki i lecheniya [Causes and forms of infertility. Modern possibilities of diagnosis and treatment]. Zdorovye zhenshchiny - Women's Health, 3, 192-197 [in Russian].

3. Masliy, Yu.V., Sudoma, I.O., \& Livshyts, H.B. (2006). 
Etiopatohenetychni chynnyky syndromu slabkoi vidpovidi yaiechnykiv $v$ tsyklakh dopomizhnykh reproduktyvnykh tekhnolohii [Ethiopathogenetic factors of ovarian poor response syndrome in cycles of assisted reproductive technology.]. Zdorovye zhenshchiny - Women's Health, 4 (28), 152-157 [in Ukrainian].

4. Mishiyeva, N.G. (2010). Besplodiye u zhenshchin pozdnego reproduktivnogo vozrasta: printsipy diagnostiki i lecheniya $v$ zavisimosti ot ovarialnogo rezerva [Infertility in women of late reproductive age: principles of diagnosis and treatment depending on the ovarian reserve]. Doctor's thesis. Moscow [in Russian].

5. Yuzko, O.M., Yuzko, T.A., \& Rudenko, N.H. (2013). Stan ta perspektyvy vykorystannia dopomizhnykh reproduktyvnykh tekhnolohii pry likuvanni bezpliddia v Ukraini [Status and prospects of using assisted reproductive technologies in the treatment of infertility in Ukraine]. Zdorovye zhenshchiny - Women's Health, 8, 26-30 [in Ukrainian].

6. Benaglia, L., Somigliana, E., Vighi, V., Ragni, G., Vercellini, P., \& Fedele, L. (2010). Rate of severe ovarian damage following surgery for endometriomas. Human Reproduction, $25,3,678-682$

7. Ben-Rafael, Z., Bider, D., Dan, U., Zolti, M., Levran, D., \& Mashiach, S. (1991). Combined gonadotropin releasing hormone agonist/human menopausal gonadotropin therapy $(\mathrm{GnRH}-\mathrm{a} /$ $\mathrm{hMG}$ ) in normal, high, and poor responders to hMG. Journal of In Vitro Fertilization and Embryo Transfer, 8, 1, 33-36.

8. Faddy, M.J., Gosden, R.G., Gougeon, A., Richardson, S.J., \& Nelson, J.F. (1992). Accelerated disappearance of ovarian follicles in mid-life: implications for forecasting menopause. $\mathrm{Hu}$ man Reproduction, 7, 10, 1342-1346.
9. Ferraretti, A.P., La Marca, A.B., Fauser, C.J.M., Tarlatzis, B., Nargund, G., \& Gianaroli, L. (2011). ESHRE consensus on the definition of "poor response" to ovarian stimulation for in vitro fertilization: the Bologna criteria. Human Reproduction, 26, 7, 1616-1624.

10. Jenkins, J.M., Davies, D.W., Devonport, H., Anthony, F.W., \& Gadd, S.C. (1991). Comparison of "poor" responders with "good" responders using a standard buserelin/human menopausal gonadotrophin regime for in-vitro fertilization. $\mathrm{Hu}$ man Reproduction, 6, 7, 918-921.

11. Keay, S.D., Liversedge, N.H., Mathur R.S., \& Jenkins, J.M. (1997). Assisted conception following poor ovarian response to gonadotrophin stimulation. The British Journal of Obstetrics and Gynaecology, 104, 5, 521-527.

12. Kolibianakis, E.M., Venetis, C.A., Diedrich, K., Tarlatzis, B.C., \& Griesinger, G. (2009). Addition of growth hormone to gonadotrophins in ovarian stimulation of poor responders treated by in-vitro fertilization: a systematic review and meta-analysis. Human Reproduction Update, 15, 6, 613-622.

13. Polyzos, N. P., Devroey, P. (2011). A systematic review of randomized trials for the treatment of poor ovarian responders: is there any light at the end of the tunnel. Fertility and Sterility, $96,5,1058-61$.

14. Surrey, E.S., \& Schoolcraft, W.B. (2000). Evaluating strategies for improving ovarian response of the poor responder undergoing assisted reproductive techniques. Fertility and Sterility, 73, 4, 667-676.

15. Ziegler, D., Borghese, B., \& Chapron, C. (2010). Endometriosis and infertility: pathophysiology and management. The Lancet, 376, 9742, 730-738. 